Christa Liedtke, Carolin Baedeker, Marco Hasselkuß, Holger Rohn, Viktor Grinewitschus

\title{
User-integrated innovation in Sustainable LivingLabs: an experimental infrastructure for researching and developing sustainable product service systems
}

Originally published as:

Christa Liedtke, Carolin Baedeker, Marco Hasselkuß, Holger Rohn, Viktor Grinewitschus (2015):

User-integrated innovation in Sustainable LivingLabs: an experimental infrastructure for researching and developing sustainable product service systems In: Journal of Cleaner Production, 97, 106-116 
User-integrated innovation in Sustainable LivingLabs:

An experimental infrastructure for researching and developing sustainable product service systems

\author{
Christa Liedtke ${ }^{1}$, Carolin Baedeker ${ }^{2}$, Marco Hasselkuß ${ }^{2}$, Holger Rohn², Viktor \\ Grinewitschus $^{3}$
}

1 Wuppertal Institute for Climate, Environment and Energy and Folkwang University of the Arts, Essen

2 Wuppertal Institute for Climate, Environment and Energy

3 Hochschule Ruhr-West, University of Applied Sciences

*Author to whom correspondence should be addressed carolin.baedeker@wupperinst.org

Doeppersberg 19

42106 Wuppertal

Germany

+49 (0)202 $2492-244$ (secretary)

\begin{abstract}
A key challenge of the 21 st century is to transform society into one that features sustainable patterns of production and consumption. To achieve this, transition processes need to be designed in key areas such as housing, mobility and nutrition. The design and large-scale implementation of sustainable product service systems (PSS) is regarded a promising approach for sustainability transitions. Real-life socio-technical experiments are an important infrastructure for designing PSS in collaboration with stakeholders and users. In this paper, we argue that transdisciplinary and action research methods are required for institutionalising an experimental set-up and developing PSS within such infrastructures. We present the Sustainable LivingLabs (SLL) research infrastructure and its methodology as an example of such experimental settings. It was collaboratively developed with key stakeholders in three consecutive research projects and applied to e.g. heating and space heating. We show new qualities of SLL in relation to existing LivingLabs and approaches for PSS design and present its methodological three-phase model (insight research, prototyping, field testing) of research. Our article contributes to knowledge on a methodological framework and tool-kit for PSS development in SLL with a clear focus on socio-ecological sustainability. Intermediate findings confirm the high influence of user practices on heating energy consumption and show starting points for PSS development: e.g. transformational products, home-automation combined with consulting along value chains. We hypothesise that developing PSS in userand stakeholder-integrated settings supports acceptance and diffusion and, by taking into account users' social practices of utilising novelties, reduces rebound effects caused by incorrect application.
\end{abstract}

Key Words: Living Lab; sustainable product service systems; experiments; open innovation; user-driven innovation; user-centred design; sustainable consumption and production; resource efficiency and protection; interactive value chains; sustainable lifestyles 


\section{Introduction}

A key challenge of the 21 st century is to transform society into one that features sustainable patterns of production and consumption. Transition processes (i.e. Geels and Schot, 2007) need to be designed in several key areas, of which housing, food and mobility are considered to be the most important in terms of environmental impact and potential rebound effects (i.e. EEA, 2013; Druckman et al., 2011). Transition is understood as a "radical, structural change of a societal (sub)system that is the result of a co-evolution of economic, cultural, technological, ecological and institutional developments at different scale-levels" (Rotmans and Loorbach, 2010). This also requires a change in lifestyle. New lifestyle trends are emerging - for instance, consumers are showing an interest in using-instead-of-owning solutions, leading to new opportunities for the development of product service systems (PSS). In turn, the spread of PSS may support such lifestyle changes (Leismann et al., 2013; Mont, 2004). Social welfare must be generated within the natural system's boundaries (Liedtke et al., 2012a; Spangenberg, 2002) in a "safe economic operating space" (Rockström et al., 2009).

Sustainable patterns cannot be achieved through technological efficiency innovations alone. Many product service innovations with a high sustainability potential fail because they are rejected by consumers or create negative rebound effects (Sorell, 2007; Druckman et al., 2011). Another important factor is unexpected user behaviour or the incorrect application of potentially sustainable efficiency innovations (Liedtke et al., 2012b; Liedtke et al., 2013a). The potential of PSS to change production and consumption systems to such an extent that sustainable transition is achieved needs to be accounted for carefully. In his typology of PSS, Tukker (2004) sees the greatest potential for environmental gains in so-called "functional results". In order to bring about a profound system transition, PSS that truly integrate technology changes in behavioural change of use patterns are required. However, such PSS may be more difficult to distribute. For this reason, it is essential that social practices of consumption and usage (Reckwitz, 2002; Warde, 2005; Røpke, 2009), routines and lifestyles are taken into account. After all, products designed for environmental efficiency under given circumstances are often used incorrectly, resulting in less sustainable outcomes than expected (Liedtke et al., 2012a).

The design and large-scale adoption of sustainable PSS - meaning the diffusion of the PSS approach amongst businesses and in consumption patterns - is often seen as a very promising approach for achieving sustainable production and consumption (e.g. Ceschin et al., 2010). PSS should enable the less material-intensive provision of services to customers by selling solutions rather than products, as Beuren et al. (2013) show in their recent literature review. However, there has not yet been a large-scale implementation of PSS.

The authors are aware that users and providers need to change their behaviour and habits in order for PSS to become widespread, which is why linking the concept of social innovation to PSS requires exploration. Scaling up sustainable PSS solutions primarily means diffusing new social practices, sometimes requiring a radical change in consumption habits and production practices. Howaldt and Schwarz $(2010,89)$ define social innovation as the intentional attempt of actors to reconfigure social practices in a designated field of action, as required for PSS diffusion. The aim is to solve problems more effectively than possible based on established 
practices. Car sharing is an example of PSS and social innovation because it challenges routine individual mobility practices (cf. Clausen et al., 2011).

Ceschin (2012) suggests drawing on results from innovation and transition research studies to achieve successful PSS implementation. Socio-technical real-life experiments that include stakeholders in the development and testing stage appear to be key to successful PSS diffusion. In this paper, we introduce the Sustainable LivingLab (SLL) research infrastructure, an example of a setting for such socio-technical experiments in PSS research and development (R\&D).

We define a Sustainable LivingLab as a locally based regional, national and international infrastructure set-up to enable innovation processes in which users and value chain-relevant actors actively participate in development, testing and marketing phases. Interactive innovation processes take place gradually in users' real life surroundings (user observation, field tests) and user interaction laboratories (e.g. for prototyping). An SLL, led by sustainability criteria, aims to contribute to global and universally applicable patterns of production and consumption, including the actor-integrated development of business cases, enabling transition processes to be marketed to companies and users. We hypothesise that by the end of this user-integrated innovation process, the PSS developed will have a greater chance of being distributed successfully (cf. Geibler et al., 2012).

The European SusLabNWE project involves setting up an international infrastructure of LivingLab test facilities and real-life experiment settings at different locations. The regional SusLabNRW ${ }^{1}$ sub-project in Germany involves setting up a heating and space heating pilot. The German consortium focuses on the Ruhr area in North Rhine-Westphalia (NRW). Here, real-life experiments are set up in the model region 'InnovationCity Ruhr, Model Town Bottrop' ${ }^{2}$ and in LL facilities (Fraunhofer inHaus, LivingLab-Container at Hochschule RuhrWest).

The German consortium addresses two key research questions:

1) How can a research infrastructure be designed that is capable of developing actorintegrated basic system innovations and achieving actor and user acceptance for their implementation? How can such an infrastructure be adapted to other regions or generalised for learning effects and upscaling, seeking to generate scientific findings about userintegrated product service innovations?

2) How can energy and resource efficiency in buildings be increased by integrating users and actors along the entire value chain of heating and space heating in the development of

\footnotetext{
${ }^{1}$ SusLabNWE receives European Regional Development Funding via INTERREG IV B new; the German SusLabNRW sub-project, part of SusLabNWE, is co-financed by the Ministry of Innovation, Science and Research of the Federal State of North Rhine-Westphalia. Scientific partners are: Wuppertal Institute for Climate, Environment, Energy; Hochschule Ruhr-West, University of Applied Sciences; Fraunhofer inHaus; InnovationCity Ruhr; involving several business partners

${ }^{2}$ The idea behind InnovationCity Ruhr, Model Town Bottrop is to transform a whole urban district with a population of about 70,000 into an exemplary district for energy efficiency by 2020. InnovationCity Ruhr is managed by InnovationCity Management $\mathrm{GmbH}$, an official partner of SusLabNRW (for more information, see http://www.bottrop.de/microsite/ic/)
} 
sustainable processes, services or products with the aim of developing sustainable PSS solutions?

The paper is structured as follows. After the introduction we present the theoretical background to SLL (Section 2) and outline the methods used to develop and advance a German SLL research infrastructure (section 3). In section 4, we discuss the outcomes of this process and how a methodology for PSS development was derived and advanced from this. Findings from insight research and their validity are presented and discussed in section 5 . In the last section, the results are discussed and conclusions drawn with regard to outstanding research tasks and perspectives for the large-scale implementation of sustainable PSS.

\section{Theoretical background to Sustainable LivingLabs}

According to Beuren et al. (2013), the PSS concept has been attracting greater attention in business and the scientific community recently. They show that the key qualities of PSS are considered to be: i) a differentiation of offerings for customers and a focus on value through solutions, providing new business cases and ii) a reduction in the environmental impact of increased consumption. Baines and colleagues defined PSS as "an integrated product and service offering that delivers value in use. A PSS offers the opportunity to decouple economic success from material consumption and hence reduce the environmental impact of economic activity" (Baines et al., 2007, 3). A PSS often redefines the contact between users and providers. When companies retain ownership, a stimulus for more (eco)efficient products is assumed (Beuren et al., 2013, 5). Tukker (2004) suggested a typology of PSS and theoretically derived respective environmental sustainability potentials, distinguishing between product-oriented, use-oriented and result-oriented services. He found that the subtype "functional results" demonstrates the greatest potential for sustainability. In this case, providers would merely offer a result, and are free to seek the most cost effective way to do so, initiating radical innovation. However, not all PSS solutions can contribute to sustainability goals such as absolute decoupling. For this reason, the sustainability potential of PSS novelties should be considered carefully throughout the development process to ensure good environmental performance. Beuren et al. (2013) state that consumers and producers experience cultural barriers, and that they need to alter their behaviour. In this respect, PSS are linked to the concept of social innovation. Developed in the SLL infrastructure, PSS are designed and evaluated throughout the process to be produced resource efficiently and to support resource-efficient user behaviour.

For this reason, we focus on explorational learning, addressing social practices and the beliefs, interpretative patterns and norms associated with them as the key potentials of PSS innovations to support change in user behaviour. In a meta perspective, the SLL approach is an applied case of a theoretical framework currently being developed at Wuppertal Institute. This theoretical Sustainable Consumption and Production Transformation Model (Liedtke et al., 2013b) aims to integrate aspects of transition research (Geels and Schot, 2007; Geels, 2011), structuration theory (Giddens, 1984), social practice theories (see below) and the psychological norm-activation model (Matthies, 2005). This coherent framework is used to analyse and support transitions of social practices towards sustainable patterns. In this sense, 
SLL aims to identify the potentials of PSS innovations to embrace social innovation (Howaldt and Schwarz, 2010).

The SLL approach builds on social practice theory for two reasons:

i) Design processes with regard to user practices may lead to greater user acceptance, making it easier to spread sustainable PSS novelties. Studies in failed innovations shown that the benefits of eco-designed products, technologies or infrastructures are hardly realised if designed without reference to user practices, as Spaargaren (2011) points out.

ii) Social practice theories are ideal for analysing routine behaviour related to a specific case study, e.g. heating.

In social practice theory, based on sociological theories by authors such as Bourdieu (1977) and Giddens (1984), practices are the basic units of social analysis. This body of theories draws on the concept of duality of structure, where practices are enacted by knowledgeable and reflexive agents drawing on virtual sets of rules and resources ("structure"), thereby (re)producing these very rules and resources. Practices are related to largely implicit knowledge, a practical know-how of doings (based on rules). They often become routinised (i.e. cooking, showering, driving to work). Thus, the interdependency between routines, technology and social norms can be scrutinised (cf. Reckwitz, 2002; Røpke, 2009; Shove et al., 2012). According to Warde (2005), practices rather than individual desires drive consumption. Unexpected user behaviour is also an important cause of rebound effects (Liedtke et al., 2012a; Peters et al., 2012). We take social practices as the basis for designing sustainable PSS and aim to reduce negative rebound effects caused by incorrect applications.

Innovation research recently highlighted the tendency of innovation processes to become increasing open, integrating stakeholders, businesses and end users in the process of developing new products or services, even at the early stage. Important concepts in this respect include the "Open Innovation" (Chesbrough, 2006) and the "Lead-user" concept (von Hippel, 1986), and the design of transformational products (Laschke et al., 2011). In this case, Open Innovation means utilising the specific inflow and outflow of knowledge across a company's borders to accelerate internal innovation (Chesbrough, 2006). Clausen et al. (2011) argue that radical innovations in particular, which may be surrounded by uncertainty concerning the market or technology, can benefit from open innovation. Non-users and leadusers may attend innovation workshops for creating sustainability innovations around the home (Diehl, 2011). 'Living Labs' (LL), first introduced at MIT to systematically observe routine activities and interactions at home, correspond to this tendency towards open innovation. A number of corresponding test facilities and approaches have since been developed but, as Bergvall-Kåreborn et al. (2009) state, there is no set definition. After reviewing the different definitions, the authors suggest defining LL as "a user-centric innovation milieu built on every-day practice and research, with an approach that facilitates user influence in open and distributed innovation processes engaging all relevant partners in real-life contexts, aiming to create sustainable values" (Bergvall-Kåreborn et al., 2009, 3). LL can also be an application of real-life experiments to urban contexts (Schneidewind and 
Scheck, 2013). One of our projects involved reviewing the LL landscape in Germany and neighbouring countries (cf. Table 1). A total of 74 labs were identified, 12 of which focus explicitly on sustainability (Geibler et al., 2013). Sustainability is not usually clearly defined and - if at all - only implicitly incorporated. The focus is mainly on economic and social sustainability (e.g. ambient-assisted living for the elderly). For this reason, ecological sustainability should be integrated more intensively.

SLL provides a setting and methodology for socio-technical real-life experiments (Groß et al., 2005; Schneidewind and Scheck, 2013) in transition processes (cf. also the phases Experiments and Learning \& Upscaling of the transition management cycle by Loorbach, 2010), which Ceschin (2012) suggests drawing on as a conceptual framework for developing and testing PSS. He concludes that experiments involving a large network of stakeholders are key to successful implementation. Building on this methodology, a toolbox of methods for integrating both users and stakeholders along value chains was developed for SLL. This toolbox takes up the idea of interactive value chains and cooperative value chain management (Schelske, 2008; Walther, 2010). SLL places users on the centre stage and integrates several other actors in cooperative value chains to develop and diffuse sustainable PSS innovations. Integrating stakeholders in experiments through transdisciplinary and action research-oriented methods provides:

i) space for interaction and social learning by stakeholders,

ii) insight into users' everyday needs and social practices in which PSS are used.

By highlighting learning processes in socio-technical experiments, SLL can help to change the behaviour of users and providers, leading to the successful implementation of PSS (see Beuren et al., 2013). The idea is not to first develop scientific knowledge about best solutions for sustainable PSS and then to disseminate the results, but to create tacit knowledge about doings, resembling user practices (cf. also Schweizer-Ries, 2013). Upscaling is then a process of diffusing newly configured social practices (social innovation) around heating. This is supported by PSS novelties and new meanings awarded to these novelties and learning processes.

Sustainability assessments of prototypes should be performed throughout the development of PSS. To this end, sustainability science has accumulated a vast amount of knowledge about tools and methods (e.g. de Ridder, 2005; Clark et. al., 2004). Many approaches, however, are limited because they usually fail to consider the entire life cycle (Baedeker et al., 2005) or indirect effects at the value chain level due to the limited knowledge available about causal links (Geibler et al., 2010). SLL addresses this problem by integrating the user as the most relevant expert (and cause of rebound effects) in the innovation process.

\section{Methods for developing a Sustainable LivingLab infrastructure}

In this section, we present the methods used in three consecutive research projects in recent years, culminating in the establishment of an experimental SLL infrastructure. The research 
methods used within the established infrastructure to develop PSS solutions are presented in Section 4.3.

Concluding from the state of the art and the theoretical background presented in Section 2, real-life experiments such as LL are a promising new field in PSS development (Ceschin, 2012; 2014). However, existing LL approaches show a lack of focus on (ecological) sustainability. A theoretical conceptualisation of user behaviour, a methodological framework for PSS R\&D and an evaluation of their sustainability potentials would hence improve the existing body of knowledge.

We therefore set out to further develop a coherent SLL infrastructure for PSS development. The aim was to identify possible fields of application, sustainability potentials and relevant stakeholders. Since SLL seeks to intervene in a given social system by designing sustainable PSS solutions that alter production, consumption patterns and contacts between producers and consumers, it is essential that prospective stakeholders (users, business, etc.) and their knowledge is integrated to inform SLL and increase acceptance. For this reason, and due to its sustainability science orientation in general, SLL research is typically transdisciplinary in nature, requiring specific methodologies (i.e. Groß et al., 2005; Scholz et al., 2006; Schneidewind, 2010; Lang et al., 2012).

Translating these requirements into appropriate methods for setting up SLL, an action research (Lewin, 1951) framework was chosen. Action research is considered to be a highly relevant methodological framework for such transdisciplinary designs because it analyses the relation between research and practice, emphasising normative references of research (Adomßent and Michelsen, 2011). It is assumed that scientific findings can only be achieved if professional researchers tackle concrete social problems and actively collaborate with 'laymen' to intervene in existing social structures. Hult and Lennung $(1980,247)$ claim it "assists in practical problem-solving and expands scientific knowledge...enhances the competencies of the respective actors, being performed collaboratively...aiming at an increased understanding of change processes in social systems." Rather than specifying methods, action research is an attitude towards research embracing a set of methods that can be used.

Expert knowledge and the involvement of stakeholders and their interests are some of the essential aspects when setting up an R\&D infrastructure and methodology such as SLL. For this reason, we opted for methods that initiate dialogue between professionals, whilst following the paradigm of action research. The table below shows which methods we used to involve key stakeholders. The consecutive projects 'LivingLab Design Study', 'Sustainability Innovations in SLLs' and advancements in 'SusLabNWE' led to the establishment of the SLL infrastructure, which is now being applied to heating in Germany, but is principally open to further applications. The main goals of the respective projects, the methods used within action research, the actors involved and a summary of the findings are presented in Table 1. 


\begin{tabular}{|c|c|c|c|c|}
\hline Project & Goals & $\begin{array}{l}\text { Action research-oriented methods } \\
\text { used }\end{array}$ & Actors involved & $\begin{array}{l}\text { Achievements/ results } \\
\text { (cf. Section 4) }\end{array}$ \\
\hline \multirow[t]{2}{*}{$\begin{array}{l}\text { LivingLab } \\
\text { Design Study } \\
(2008-2010)^{3}\end{array}$} & \multirow{2}{*}{ 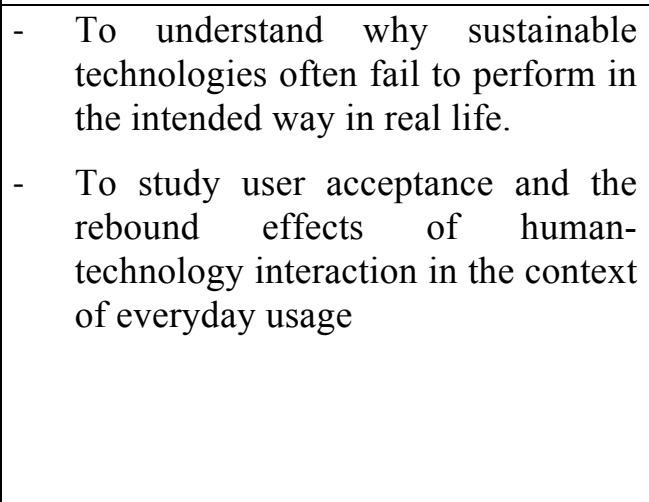 } & $\begin{array}{l}\text { Feedback in expert workshops/ } \\
\text { evaluation of potentials for } \\
\text { sustainability innovations to provide } \\
\text { high stakeholder acceptance and to } \\
\text { integrate expert knowledge }\end{array}$ & $\begin{array}{l}\text { Classification of potential } \\
\text { stakeholders (research, } \\
\text { business, NGOs, consumer } \\
\text { organisations, public } \\
\text { authorities) }\end{array}$ & $\begin{array}{l}\text { Three-Step Model of } \\
\text { Research (Bakker et al., 2010) }\end{array}$ \\
\hline & & $\begin{array}{l}\text { Stakeholder-integrated foresight } \\
\text { Project-internal expert panel: } \\
\text { screening societal megatrends } \\
\text { Evaluation/validation with all } \\
\text { stakeholders involved in the project }\end{array}$ & $\begin{array}{l}\text { Experts from business, } \\
\text { (interdisciplinary) research, } \\
\text { the European Commission }\end{array}$ & $\begin{array}{l}\text { Five generic research lines for } \\
\text { R\&D in living labs (Welfens } \\
\text { et al., 2010) } \\
\text { (cf. Section 4) }\end{array}$ \\
\hline $\begin{array}{l}\text { Sustainability } \\
\text { Innovations } \\
\text { in SLLs } \\
(2011-2012)^{4}\end{array}$ & $\begin{array}{ll}\text { - } & \text { To screen the German R\&D } \\
\text { landscape for connecting points } \\
\text { - } & \text { To identify technologies and } \\
\text { product and service fields that } \\
\text { demonstrate a high potential for } \\
\text { sustainability } \\
\text { - } & \text { To initiate and implement } \\
\text { continuous stakeholder dialogue } \\
\text { - }\end{array}$ & $\begin{array}{l}\text { Interviews with experts } \\
\text { Several dialogue workshops for } \\
\text { validating and readjusting } \\
\text { hypotheses and findings }\end{array}$ & $\begin{array}{l}\text { Experts from } \\
\text { (interdisciplinary) research, } \\
\text { business, design } \\
\text { organisations, other living lab } \\
\text { facilities, associations }\end{array}$ & $\begin{array}{l}\text { SLL provides the opportunity } \\
\text { to: } \\
\text { - improve the climate for } \\
\text { creating sustainable PSS } \\
\text { - advance the development } \\
\text { of resource-efficient, } \\
\text { competitive and socially } \\
\text { compliant PSS } \\
\text { institutionalise } \\
\text { improve access to a } \\
\text { research infrastructure for } \\
\text { companies and research }\end{array}$ \\
\hline
\end{tabular}

\footnotetext{
${ }^{3}$ The European Design Study was financed within the 7th Framework Programme of the European Union (2008-2010) and conducted by four academic partners (led by TU Delft in cooperation with ETH Zurich, Universidad Politecnica de Madrid, Wuppertal Institute) and three industrial partners (ACCIONA, BASF, Procter \& Gamble).

${ }^{4}$ The project "Sustainability Innovations in SLLs" was conducted by Wuppertal Institute in cooperation with Fraunhofer IAO, Fraunhofer ISI and Faktor 10 - Institute, funded by the German Federal Ministry of Education and Research (2011-2012).
} 


\begin{tabular}{|c|c|c|c|c|}
\hline & & & & $\begin{array}{l}\text { institutes without their } \\
\text { own SLL structure via } \\
\text { pan-European networks } \\
\text { (Geibler et al., 2013) }\end{array}$ \\
\hline $\begin{array}{l}\text { SusLabNWE/ } \\
\text { SusLabNRW } \\
(2012-2015)\end{array}$ & 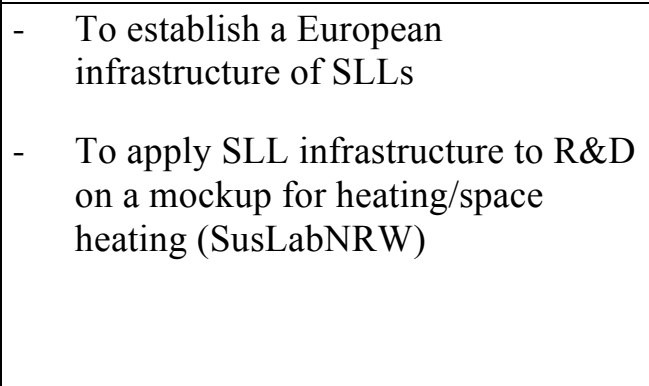 & $\begin{array}{l}\text { Application of methods toolkit (see } \\
\text { Section } 4.2 \text { and Figure 3): action } \\
\text { research and development of PSS }\end{array}$ & $\begin{array}{l}\text { Users, several European } \\
\text { research partners, business } \\
\text { partners, funding agencies }\end{array}$ & $\begin{array}{l}\text { Intermediate results: } \\
\text { - } \quad \text { Methodological Three- } \\
\text { Phase Model (based on the } \\
\text { Three-Step Model) } \\
\text { - } \begin{array}{l}\text { Results on heating } \\
\text { practices from insight } \\
\text { research }\end{array}\end{array}$ \\
\hline
\end{tabular}

Table 1: Projects conducted to establish the SLL infrastructure 


\section{Results: The Sustainable LivingLabs research infrastructure and its implementation in the German SusLabNRW project}

In this section, we outline the results of the collaborative research process, presented in Section 3, leading to the Sustainable LivingLab infrastructure and methodology. We discuss what is new about this infrastructure and which desiderata of research into living labs are addressed (Section 4.1). The methodological three-phase model of the R\&D of sustainable PSS solutions is then introduced as a central result of the current German SusLabNRW subproject (Section 4.2).

One central result of the design study was the identification of the following five generic research lines, helping to structure the potentially broad scope of a living lab.

\begin{tabular}{|l|l|}
\hline Sustainable homes & $\begin{array}{l}\text { Collaborative development and testing of easily installable user- } \\
\text { friendly systems or materials that can easily be dismantled, separated or } \\
\text { reused. }\end{array}$ \\
\hline $\begin{array}{l}\text { Integrated approaches } \\
\text { for home energy } \\
\text { management }\end{array}$ & $\begin{array}{l}\text { The focus is on developing interaction designs and smart systems } \\
\text { (smart meters and grids) that can encourage and help residents to save } \\
\text { resources. }\end{array}$ \\
\hline The connected home & $\begin{array}{l}\text { The scope of LivingLab research questions should be extended to } \\
\text { activities beyond the home: implications of the on-going virtualisation } \\
\text { of working, social interaction and consumption. }\end{array}$ \\
\hline $\begin{array}{l}\text { Resource-efficient } \\
\text { lifestyles and social } \\
\text { networks }\end{array}$ & $\begin{array}{l}\text { Study of lifestyles and consumption patterns in a real-world setting: the } \\
\text { role of user's motivations and pleasure connected to socially } \\
\text { constituted ways of using a certain product or service, forming social } \\
\text { practices of consumption. }\end{array}$ \\
\hline $\begin{array}{l}\text { Development of a new } \\
\text { product or service }\end{array}$ & $\begin{array}{l}\text { "Products with significant environmental effects in the use phase } \\
\text { should be developed in LivingLab with a clear focus on the user } \\
\text { context to prevent unwanted side effects" (Liedtke et al., 2012b: 12). }\end{array}$ \\
\hline
\end{tabular}

Table 2: Five generic research lines for SLL identified in the LivingLab Design Study (Source: Welfens et al., 2010)

In the course of 'Sustainability Innovations in SLLs', opportunities and risks involved in establishing a German SLL infrastructure were identified (Geibler et al., 2012): opportunities include linking existing research strands of user integration and sustainability science, which are largely unconnected. However, there are also important barriers. The short-term logic of business strategies sometimes encounters the insecure or delayed commercial utilisation of sustainable PSS solutions. In addition, non-ideal technological predeterminations due to the selection of partners, for instance, may occur and data protection problems must be addressed because SLL involves the collection of sensitive user data. Focusing on resource conservation, LL is promising for the fields of 'living and working', 'cities, regions and mobility' and 'retail and gastronomy' (Geibler et al., 2013). 


\subsection{New features of the Sustainable LivingLab}

Compared to existing living lab approaches (cf. Section 2), we believe the SLL infrastructure offers a number of new qualities. In addition to our clear focus on sustainability innovations, the systematic connection of PSS development to LL is not yet an established field of research. Furthermore, SLL offers the unique combination of laboratory situations in LL with real-life experiments in a German urban district in which households are asked to become involved in the development process on a voluntary basis.

To our knowledge, the European infrastructure and methodological framework developed (Three-phase model of research) is unique.
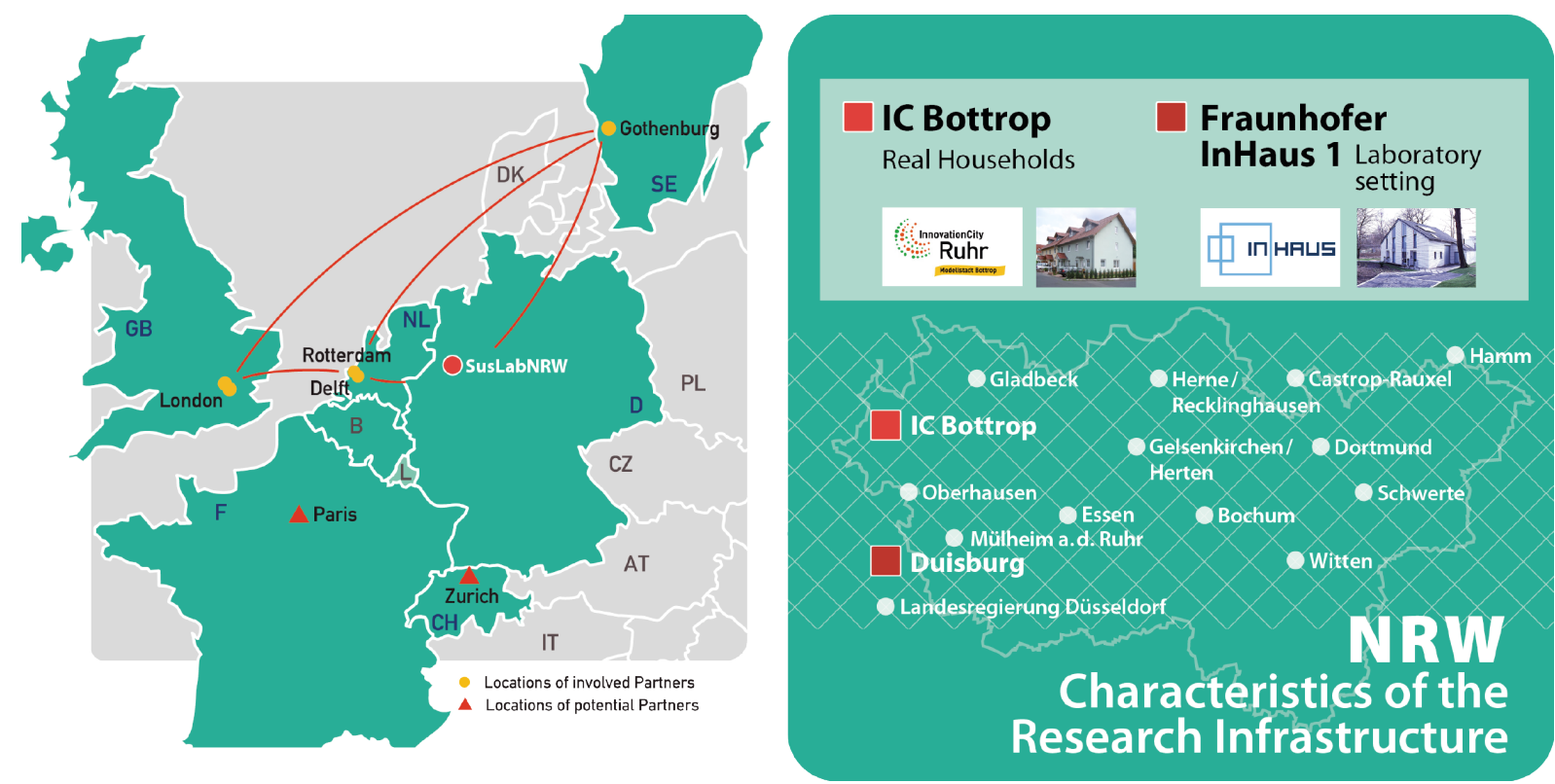

Figure 1: The SusLabNWE consortium and the German SusLabNRW research infrastructure

The combination of LL and real-life experiments in the urban district constitutes the set-up for socio-technical experiments for developing PSS, applied in this case to heating and space heating. According to Wood and Newborough (2003), research shows that between 26 and $36 \%$ of in-home energy consumption is caused by user behaviour. Messerschmidt (2012) argues that, combined with more efficient heating systems, optimised user behaviour can save between 10 and $30 \%$ of heating energy. For this reason, focusing on heating practices offers potential for sustainability transitions in this field.

\subsection{The advanced three-phase model of research}

In this section we describe the methods used within the SLL infrastructure in order to conduct R\&D of PSS solutions. We outline the research design (three-phase model of research, Figure 2) applied to the Sustainable LivingLabs (SLL) approach in SusLabNRW. This design was achieved by addressing the five generic research lines, the three-step model of research and the idea of living laboratories for sustainable innovation, and advancing the methodological basis. 


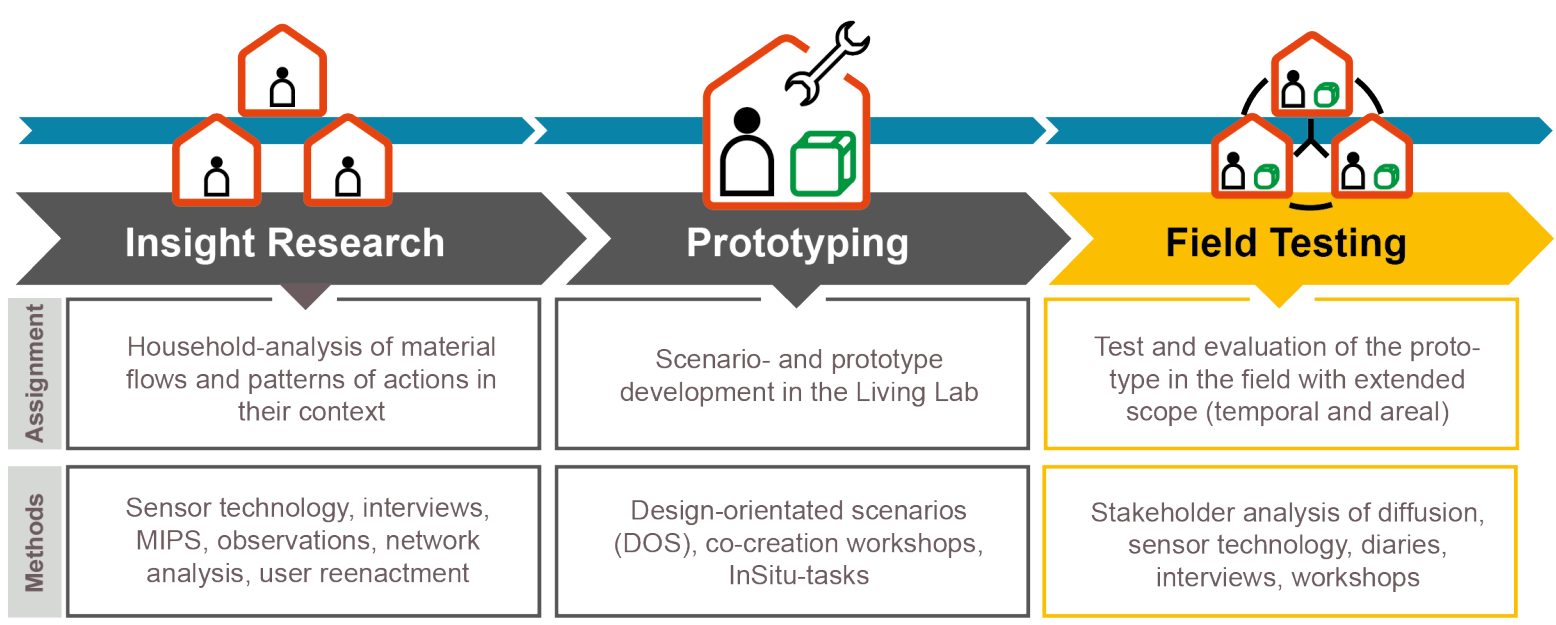

Figure 2: The Sustainable LivingLabs three-phase model of research

\section{Research methods in the three-phase model - the design of the German SusLabNRW}

Research is conducted in both real households in the experimental area of InnovationCity Ruhr and in living lab facilities. The combination of methods with a multi-disciplinary background is key to developing sustainable PSS solutions to support transition processes. Figure 3 shows how the different methods interrelate.

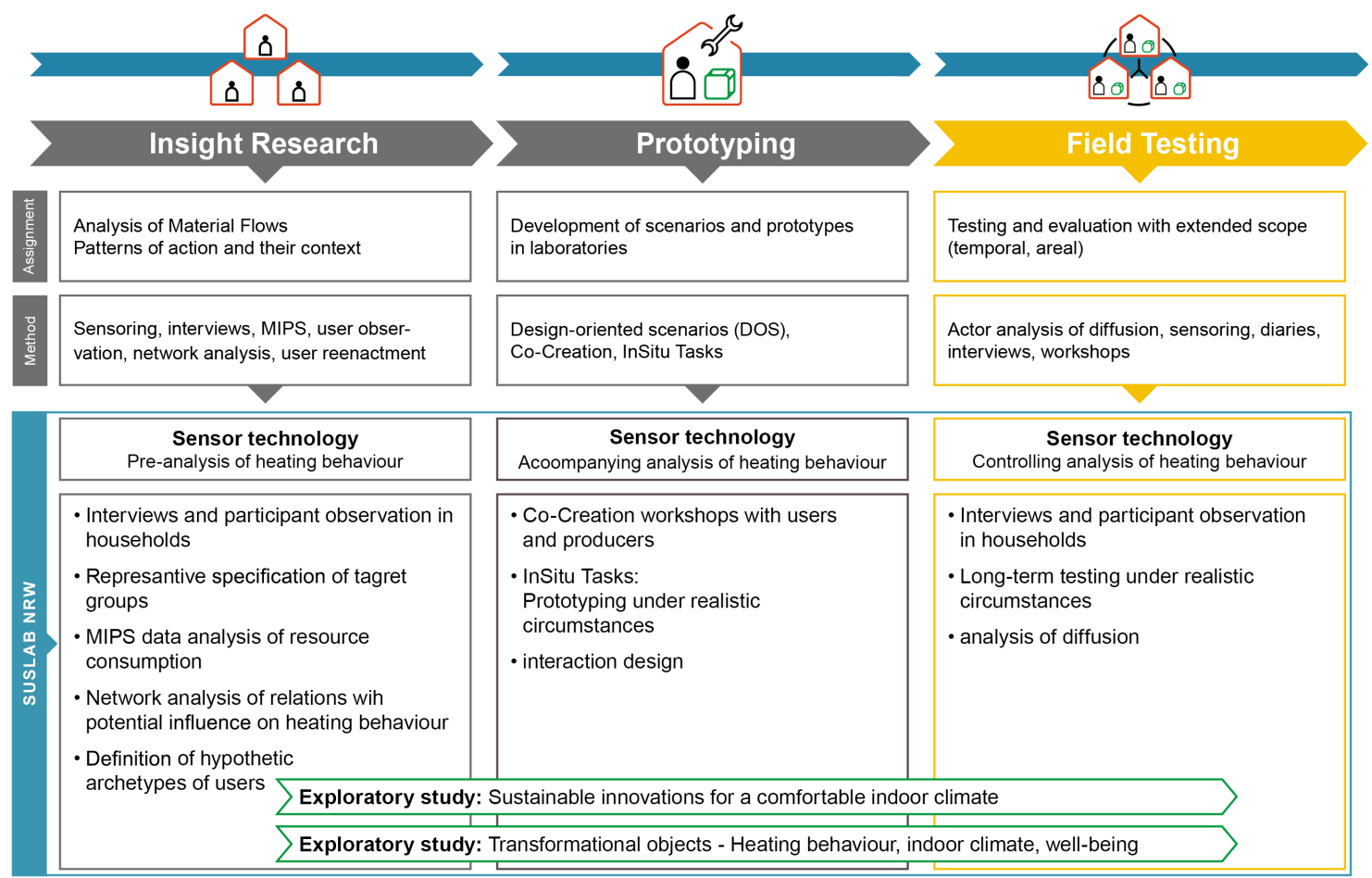

Figure 3: Case study design: methods applied in the three-phase model in SusLabNRW 


\section{Experimental and interactive research design}

Accordingly, the aim is not only to develop sustainable PSS novelties, but to contribute to a culture of resource awareness, e.g. in business (Bliesner et al., 2013). Establishing an interactive, experimental space for PSS development appears to be a promising way of achieving this. SLL aims to go beyond merely observing users or integrating some of their ideas into sustainability innovations.

The stakeholders to be involved should be heterogeneous. They should always be selected in line with the focus of the PSS to be designed, in this case heating/space heating (Ceschin, 2014). SusLabNRW therefore involves users, scientists, business partners, partners and policy stakeholders. In sustainable PSS development, the user takes the centre stage as the most relevant expert and cause of potential rebound effects. Details about the research design based on the three-phase model are given below.

\subsubsection{Insight research}

The first phase of insight research involves understanding the status quo of building characteristics, heating energy consumption and related social practices and interpretative schemes around heating. How much influence do user practices have when users interact with heating systems, energy efficiency (insulation, efficient heating systems, etc.) and energy awareness systems in buildings? Social research methods (qualitative interviews and social network analysis: Lamnek, 2010; Hollstein and Straus, 2006; Prell, 2012), sustainability accounting (material footprint MIPS analysis: Schmidt-Bleek 1994; Schmidt-Bleek et al., 1998), sensor technology (data logging) are combined in a mixed-methods approach.

First, a pre-analysis of building characteristics was conducted in which heating energy consumption for different types of buildings in InnovationCity Ruhr was compared (sample based on quantitative data on cost structure for heating energy by the Housing Society VivaWest and InnovationCity Management). Qualitative interview data was collected simultaneously alongside a consulting programme conducted in Bottrop.

Mobile data loggers equipped with sensor technology were installed in 80 participating households in Bottrop. These data loggers remained in the households for two weeks, recording the concentration of $\mathrm{CO} 2$, humidity and room temperature every three minutes. In addition, the residents noted when they were at home, when they opened a window and for how long. Wherever possible, energy consumption was monitored throughout the data logging period, or at least once a day.

During insight research, users are not only researched but interactively integrated as the most important stakeholders. They were given feedback about their resource and energy consumption, and a voluntary workshop was held on potential improvements. Feedback about the data logging process was very positive, with household members stating that they had forgotten the loggers existed after just a few days. This is an important aspect for data validity concerning a possible bias when applying data loggers. However, household members expressed a need for better feedback material. These suggestions will be incorporated into 
future measurement activities. For the purpose of validation, data logging will be repeated in future heating periods to identify measurement weaknesses and to validate the methods and findings.

Transformational objects (Hassenzahl and Laschke, 2013) are designed in parallel. Based on the feedback workshop involving households, a sample of six households was selected (three households exhibiting "good" airing methods and temperature levels and three households with rather adverse behaviour in this respect). We took this as an indicator to delve deeper into social practices. Semi-structured qualitative interviews and participant observation methods (cf. Lamnek, 2010 for details on methods) were conducted: inhabitants were asked to show artefacts in their flats which they consider important for comfort/warmth, and how they use them. Participant observation also considers non-verbal information and unconscious actions. This is crucial because social practices concerning heating are assumed to be largely routinised. Using geo-milieu data and questionnaires, the 80 participating households were assigned to target groups and social milieus. Building on this information, households were representatively chosen for a MIPS data analysis, described below. The results constitute a design space for conceptualising transformational objects (see Section 4.2.2).

Social influence in personal networks, such as advice on saving energy and how to set up the heating system, as well as the influence of a household's peer group in terms of norms and status, can be important factors in heating behaviour. In order to analyse a household's embeddedness in social networks, a mixed-methods social network analysis (Prell, 2012; Hollstein and Straus, 2006) was conducted. Network analysis provides empirical data on the actual relationships of households that may influence their heating behaviour. Interviews were conducted with around 15 households (including lead users and non-lead users; inhabitants of one-family dwellings and apartment buildings; different socio-economic attributes). Personal relations (friends, neighbours, relatives and peer groups) and relations to actors in the value chain of heating/space heating (i.e. craftspeople, manufacturers) were analysed, resulting in ego-network maps. Which relevant actors can be identified and what evidence of their influence can be found? How do households interpret such influences in their heating behaviour? Preliminary results indicate that contacts with family and friends play a major role and that consulting agencies and consumer advice centres influence decisions on investments in insulation, for example, to a great extent - due to the highly developed infrastructure of consulting in Innovation City Ruhr. Institutions seem to work and it shows that advice is also further diffused through ego-networks.

Since it can be assumed that routine practices surrounding heating energy consumption are also related to practices involving high material intensity in other fields, a material footprint analysis (MIPS) will be performed for seven different consumption fields in around 12 selected households. What behavioural "hot spots" in the use of resources and energy can be identified? Which are the most relevant improvements that can be derived from this? How can the results be put into practice by users and producers? MIPS (Schmidt-Bleek, 1994; SchmidtBleek et al., 1998) allows the environmental impacts caused by a product or service to be estimated, considering the whole life cycle from cradle to cradle, by dividing material input (MI) by the service unit. MIPS was chosen because it is the only input-based indicator 
available at present that focuses on resource consumption along whole value chains. MIPS is sometimes criticised for its failure to assess ecotoxicity. If MIPS is chosen as a design tool, however, ecotoxicity must be avoided to the greatest extent possible and explicated whenever it occurs. MI covers all resources removed from nature and transferred into the technosphere. A MIPS analysis has already been applied successfully to household analysis in a Finnish study (Lettenmeier et al., 2012). Participants responded to a detailed questionnaire on the type of building they inhabit, the type of heating system they have and their consumption behaviour in various fields.

\subsubsection{Prototyping}

In the second phase (prototyping), different methods are combined to integrate the project's relevant stakeholders into the development of a sustainable PSS solution for heating and space heating - mainly users and business partners. Together with business partners in SusLabNRW, marketable product solutions are currently being tested as assisting functions in heating and airing behaviour:

- A wallpaper that functions as indoor insulation

- Smart home systems

- $\mathrm{CO} 2$ signal light, indicating the indoor $\mathrm{CO} 2$ concentration

- Combined sensor toolkit monitoring temperature, humidity and CO2 concentration, providing users with feedback. The toolkit records a baseline and data for comparison when using the product.

All of the results generated by these tests and from insight research will be evaluated through repeated data logging and interviews in participating households, and incorporated into CoCreation Workshops (i.e. Sanders and Stappers, 2008) for the actual development of PSS solutions in order to find custom-fit service offerings alongside the assisting functions. The workshops build on findings, e.g. weaknesses identified along value chain(s) to support user practices. How should consulting be designed to truly reach users and at which stage along the value chain is additional consulting necessary? The objective is to generate ideas and to integrate participants' knowledge into the design of prototypes.

As indicated above, prototypes for transformational products will be developed and installed along with data loggers in households that demonstrated rather adverse practices. This is another step in the validation of intermediate results that is integrated into PSS development in the sense of feedback loops. The idea of transformational objects is to design "pleasurable troublemakers", capable of creating "complex, meaningful personal and social situations" (Hassenzahl and Laschke, 2013). Instead of automating processes, transformational objects intervene at the right spot and prevent us from acting on impulse (i.e. leaving the heating on while a window is open) and to instead reflect upon our action. In contrast to more subtle "nudging" approaches, transformational objects remind users of "bad" habits and a conscious need to take action - this is thought to support learning processes. In addition, the prototypes developed are validated using a broad-based online survey about which concepts users think fit best. 


\subsubsection{Field testing}

In this phase, developments are evaluated and redesigned if necessary. Methods similar to the first phase are employed in order to evaluate the performance and acceptance of PSS novelties in the field. Prototypes (i.e. transformational products) together with developed services around the prototype should be distributed to a larger number of real households. Installing data loggers and measuring energy consumption provides feedback on the performance of the PSS developed. This phase cannot, however, be conducted in the scope of SusLabNRW, and is currently being envisaged for later projects.

\section{Findings}

At the current stage of research, we believe that our study can mainly contribute to the following aspects. First, because socio-ecological sustainability is not considered systematically in existing LL, we will be able to establish a consistent European infrastructure of labs, focusing clearly on sustainability innovations and the evaluation of their potentials.

Second, the methodological three-phase model appears to make an important contribution to knowledge about how to design, research and develop PSS in LL and real-life experiments. Developing methods for the open innovation process is one of the most important contributions of research as a stakeholder in LL processes (Schuurman et al, 2011). Since PSS design is starting to consider the relevance of user integration in real-life experiments (Ceschin, 2014), our approach contributes to advancing this research strand. The methodology, however, is not a static approach, but is advanced throughout the project using the results of different phases. Thus, we cannot yet fully validate our results regarding the feasibility of the SLL methodology for developing sustainable PSS. This form of openness towards the validation of results, however, is a necessary quality of action research and transdisciplinary designs.

Third, the intermediate results of insight research add to the current state of research into how user behaviour influences heating energy consumption. The results of our pre-analysis and data logging in 80 households support our hypothesis that user behaviour has a major impact (primarily due to their heating and airing practices) and can annul the effects of high investment technical measures because these are often not attuned to user behaviour. Socalled heat maps were generated to analyse the data loggers (Figure 4), showing the CO2 concentration and room temperature in the participants' living room every three minutes over a two-week period. The x-axis represents the days on which the measurements were taken; the $y$-axis represents the time of day. The colour bars on the right-hand side of the diagrams show the value range for $\mathrm{CO} 2$ concentration ( $\mathrm{ppm}$ ) and room temperature (degrees Celsius). 

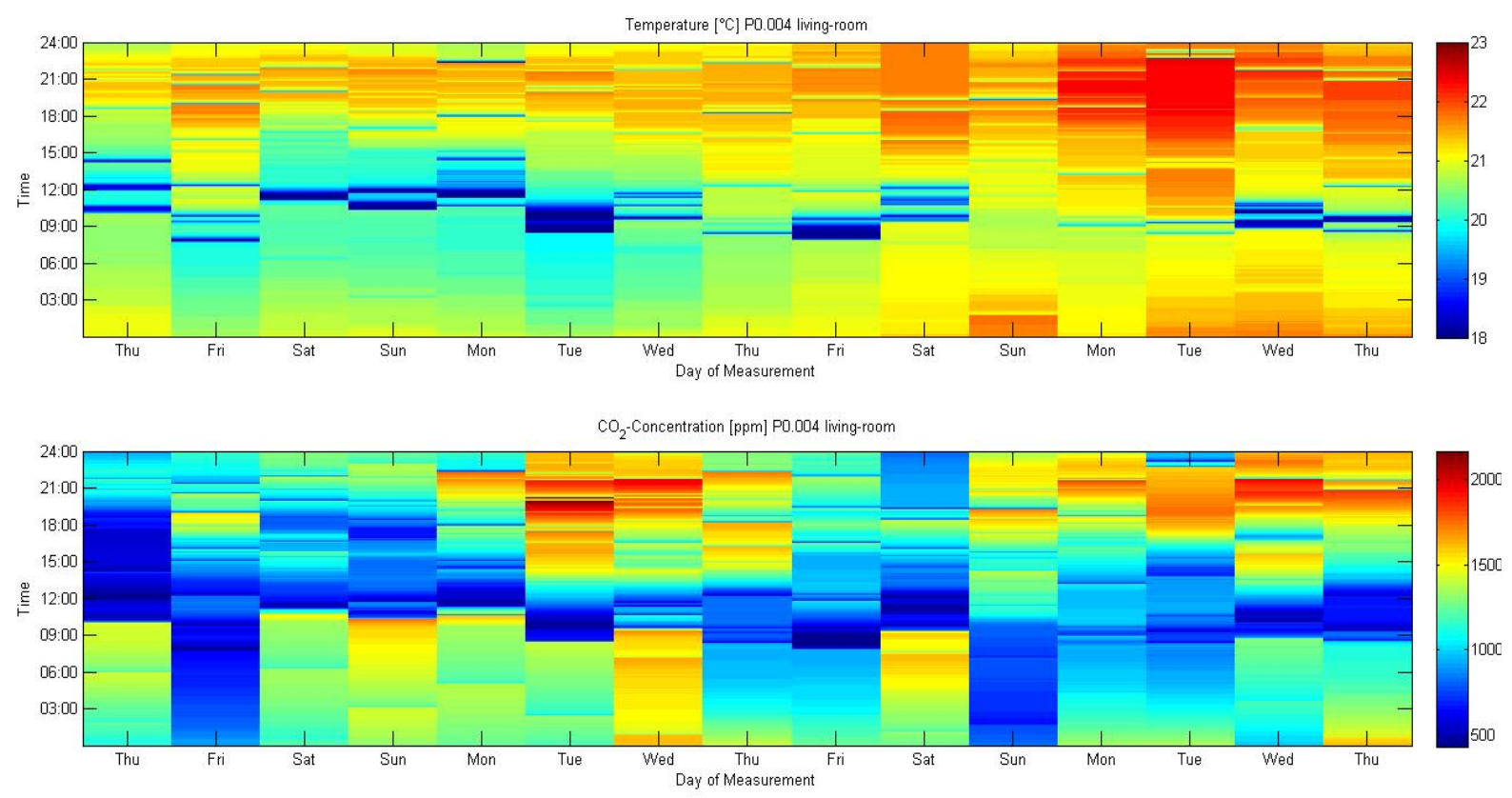

Figure 4: Example of a heat map

In this flat, heating energy consumption was above average, which seems to be caused by improperly long airing cycles (up to two hours). The quality of the room air, indicated by the $\mathrm{CO} 2$ concentration, however, is good due to this kind of airing.

Our analysis indicates there is no clear correlation between the age of the building or the heating system and heating energy consumption. The average room temperatures vary greatly between 16 and 26 degrees Celsius, and are often very constant, even at night. The heating maps proved that user behaviour has a huge impact on the consumption of heating energy. Differences of a factor of 5 to 7 are possible in the same kind of houses with the same heating systems (Grinewitschus et al., 2013). Data logging suggests that the reasons for such differences are the actual heating systems and their set-up, as well as user behaviour:

- Regarding the heating system, the night setback often does not work properly (around one-third of participants), even if it is installed and is standard equipment nowadays. In addition, wrong set-ups were often found, i.e. the heating pump was set too high or heating characteristics for the outdoor temperature were installed incorrectly. Households with automatically timed temperature adjustments for each individual room tend to consume less heating energy, and temperature differences between night and day time are larger.

- User influence: Households that consume less heating energy generally exhibit shorter airing periods, since short periods lead to a less significant drop in room temperature. Summarising the qualitative interview material, heating practices in the six households can be constructed. Examples include: the T-shirt climate family that wants to have an indoor climate so that they can wear light clothing at home all year round. The verify guy who always wants to control the heating system manually and uses thermometers to check for room temperature in relation to his personal comfort. 
The family with multiple energy sources, which is unhappy about the complexity of a newly installed heating system and the time they spend managing the different energy sources. These insights into practices provide starting points for designing transformational products, e.g. addressing the structure behind them.

In addition, weaknesses along current value chains around the provision of the service "warmth at home" were identified. Besides inappropriate use patterns, incorrect heating systems set-ups and difficulties in understanding many heating systems was a problem identified frequently during insight research. The intermediate results generated by insight research are currently being discussed with business partners to identify which sustainable PSS solutions may be interesting to these stakeholders. For example, a heating system manufacturer is currently testing specific modules for room temperature control, i.e. a product innovation in SLL (see above). However, the manufacturer is well aware of the potentials involved in contacting end users directly, which is usually implemented via a network of handicraft companies that maintains households' heating systems. This service component in the PSS of providing space heating is an interesting starting point because it involves the complex installation of the system as well as advice on how to use it in the most efficient way. The manufacturer appears to be interested in combining more resource-efficient heating systems with the provision of services. Here, the potential for the remainder of the project will be to incorporate the results about actual user practices into a sustainable PSS solution, which could include continuous consultation for end users. It shows that business is aware of PSS solutions, but awareness needs to be raised of service requirements along the value chain and the critical assessment of sustainability potentials. In order to achieve this, SLL seeks to evaluate sustainability potentials for the PSS developed with regard to user practices. The repeated implementation of data loggers in real households following the development of prototypes is an example of such phase- and interstage-specific validation of resource and energy conservation potentials.

\section{Conclusions}

In this paper, we described the theoretical background of the SLL infrastructure installed for PSS development, and how it was developed. We then presented new qualities of SLL as reallife experiments and the methods used along the three-phase model as a new methodological framework to accompany PSS innovation. Our intermediate empirical results on development for a PSS solution in heating in Germany support our assumption that the influence of user behaviour outweighs other investment-heavy measures, such as highly efficient heating systems and thermal insulation, which may even have the opposite effect. This result is also supported by the work of Sunikka-Blank and Galvin (2012), who found that the energy consumption of residents in energy-efficient buildings is sometimes above average and that behavioural effects are often underestimated. Predicted savings from thermal insulation or more efficient heating systems are often not achieved in practice. Without regard to user practices, there is a risk that the effects of such measures will vanish. It appears that inhabitants tend to continue their habits, i.e. their social practices. For this reason, PSS should primarily address a change in users' social practices and induce social innovation. To this end, 
prototypes will concentrate on value through product service solutions, meaning the provision of the subjective feeling of comfortable warmth and assistance in heating energy consumption, rather than the product "heating system". The PSS should consist of a tangible product - assisting functions in the home and/or transformational products - accompanied by a system of services. These services could include training craftspeople how to maintain such systems or custom-fit consultation for users.

In this paper, we argued the importance of an SLL infrastructure for developing sustainable PSS solutions. We advanced this infrastructure in a collaborative process, orientated towards action research methods, in a series of interlinked projects with several scientific and business partners. In line with Ceschin (2012), this infrastructure is itself a setting for collaborative research and stakeholder integration into PSS development. At this stage of research, we cannot yet fully validate our results or the feasibility of the infrastructure. We nevertheless found support for the hypothesis that the possibility for all stakeholders to participate in social learning processes provides a good basis for the later acceptance and implementation of PSS. Both business partners and users can relate to PSS solutions because they were involved in the innovation process. Knowledge produced is expected to be closer to practices in the field and less theoretical. However, the process should be guided by researchers, and adequate didactic material should be provided. Socio-technical experiments provide an appropriate setting for the collaborative development of solutions and the time required to get used to them. Building up a stakeholder network also opens up channels for the spread of innovation. In transition research, it is argued that single experiments do not lead to regime change and, therefore, a sequence of first local experiments should be performed (Geels and Raven, 2006) and replicated in different settings and contexts (van den Bosch 2010). The SLL infrastructure is established at different European locations in order to replicate experiments in future fields of application (e.g. sustainable PSS in mobility or nutrition). Thus, experiments could gradually reinforce one another, as van den Bosch (2010) argues, and stakeholder learning in the SLL setting can hopefully contribute to the cultural changes that are required in the long run. These are the next steps that need to be taken in research into sustainable PSS in order to support their diffusion, since transferring lessons from experiments to other contexts will always come up against limitations. Nevertheless, sustainability potentials have to be measured using adequate indicators during all phases of development, and the SLL infrastructure needs to overcome important barriers, as Geibler et al. (2013) have shown.

\section{References}

Adomßent, M., Michelsen, G., 2011. Transdisziplinäre Nachhaltigkeitswissenschaften, in: Heinrichs, H., Kuhn, K., Newig, J. (Eds.), Nachhaltige Gesellschaft. Welche Rolle für Partizipation und Kooperation? VS Verlag für Sozialwissenschaften, Wiesbaden, pp. 98-116.

Baedeker, C. et al., 2005. Analyse vorhandener Konzepte zur Messung des nachhaltigen Konsums in Deutschland einschließlich der Grundzüge eines Entwicklungskonzeptes. Project report.

Wuppertal Institute for Climate, Environment, Energy, Wuppertal. http://www.wupperinst.org/uploads/tx_wiprojekt/messung-nachh-konsum.pdf (Accessed 8 January 2013). 
Baines, T. S., Lightfoot, H. W., Evans, S., Neely, A., Greenough, R., Peppard, J., Roy, R., et al., 2007. State-of-the-art in product-servicesystems, Proceedings of The Institution of Mechanical Engineers. Part B-Journal of Engineering Manufacture 221(10), 1543-1552.

Bakker, C. et al., 2010. LivingLab: Summary Report, forthcoming.

Bergvall-Kåreborn, B., Ihlström Eriksson, C., Ståhlbröst, A., Svensson, J., 2009. A milieu for innovation-defining living labs. In 2nd ISPIM Innovation Symposium, New York.

Beuren, F.H., Gomes Ferreira, M.G., Cauchick Miguel, P.A., 2013. Product-service systems: a literature review on integrated products and services. Journal of Cleaner Production (in Press). Available at: http://dx.doi.org/10.1016/j.jclepro.2012.12.028 (Accessed 21 March 2013)

Bliesner, A., Liedtke, C., Rohn, H, 2013. Resource efficiency and culture - Workplace training for small and medium-sized enterprises, Science of The Total Environment (in Press), Available online at: http://dx.doi.org/10.1016/j.scitotenv.2013.11.053 (Accessed 31 January 2014).

Bourdieu, P., 1977. Outline of a Theory of Practice. Cambridge University Press, Cambridge.

Ceschin, F., 2014. Sustainable Product-Service Systems. Between Strategic Design and Transition Studies. Springer International Publishing.

Ceschin, F., 2012. Critical factors for implementing and diffusing sustainable product-Service systems: insights from innovation studies and companies experiences. Journal of Cleaner Production (in Press). http://dx.doi.org/10.1016/j.jclepro.2012.05.034 (Accessed 21 March 2013)

Ceschin, F., Vezzoli, C., Zingale, S., 2010. An aesthetic for sustainable interactions in product-service systems?. http://bura.brunel.ac.uk/bitstream/2438/6727/2/Fulltext.pdf (Accessed 23 October 2013).

Chesbrough, H.W., 2006. Open Innovation: A New Paradigm for Understanding Industrial Innovation, in: Chesbrough, H.W., Vanhaverbeke, W., West, J. (Eds.), Open Innovation: Researching a new paradigm. Oxford University Press, New York, pp.1-14.

Clark, W. C., Crutzen, P. J., Schellnhuber, H. J., 2004. Science for global sustainability, in: Schellnhuber, H. J. et al. (Eds.), Earth system analysis for sustainability. Dahlem Workshop Report 91, MIT Press, Cambridge, pp. 1-28.

Clausen, J., Fichter, K., Winter, W., 2011. Theoretische Grundlagen für die Erklärung von Diffusionsverläufen von Nachhaltigkeitsinnovationen.

http://www.borderstep.de/popup_firstvisitor.php?pdf=V-Clausen-Fichter-WinterTheoretische_Grundlagen_fuer_die_Erklaerung_von_Diffusionsverlaeufen_von_Nachhaltigkeit sinnovationen-2011.pdf (Accessed 8 January 2013).

De Ridder, W., 2005. Sustainability A-Test: Inception report. [online] Report no 555000001 from the Netherlands Environmental Assessment Agency. http://www.rivm.nl/bibliotheek/rapporten/555000001.pdf (Accessed 8 January 2013).

Diehl, B., 2011. Nachhaltigkeitsinnovationen im Bedarfsfeld Wohnen, in: Belz, F.M., Schrader, U., Arnold, M. (Eds.), Nachhaltigkeitsinnovationen durch Nutzerintegration. Metropolis, Marburg, pp. 121-144.

Druckman, A., Chitnis, M., Sorell, S., Jackson, T., 2011. Missing carbon reductions? Exploring rebound and backfire effects in UK households. Energy Policy 39(6), 3572-3581. 
EEA, 2013. Environmental pressures from European consumption and production. A study in integrated environmental and economic analysis. Technical Report No 2/2013. European Environment Agency, Copenhagen.

http://www.eea.europa.eu/publications/environmental-pressures-from-europeanconsumption/at_download/file (Accessed 31 October 2013).

Geels, F.W., Schot, J.W., 2007. Typology of sociotechnical transition pathways. Research Policy 36(3), 399-417.

Geels, F.W., Raven, R.P.J.M., 2006. Non-linearity and expectations in niche-development trajectories: Ups and downs in Dutch biogas development (1973-2003). Technology Analysis \& Strategic Management 18, 375-392.

Geibler, J.v., Erdmann, L., Liedtke, C., Rohn, H., Stabe, M., Berner, S., Jordan, N. D., Leismann, K., Schnalzer, K., 2013. Living Labs für nachhaltige Entwicklung: Potenziale einer Forschungsinfrastruktur zur Nutzerintegration in der Entwicklung von Produkt- und Dienstleistungen. Wuppertal Spezial No. 47. Wuppertal Institute for Climate, Environment, Energy, Wuppertal. http://wupperinst.org/en/publications/details/wi/a/s/ad/2270/ (Accessed 31 October 2013).

Geibler, J.v., Baedeker, C., Hasselkuß, M., Jordan, N.D., Rohn, H., 2012. Living labs as a reflexive user-driven research infrastructure to promote sustainable consumption and production patterns: Experiences from exploratory research, 18th Annual Conference of the International Sustainable Development Research Society (ISDRS): Conference Proceedings, Hull.

http://www2.hull.ac.uk/science/isdrc18/conference-proceedings.aspx (Accessed 22 March 2013, password required).

Geibler, J.v., Kristof, K., Bienge, K., 2010. Sustainability assessment of entire forest value chains: Integrating stakeholder perspectives and indicators in decision support tools. Ecological Modelling 221(18), 2206-2214.

Giddens, A., 1984. The Constitution of Society: outline of the Theory of Structuration. University of California Press, Berkeley/Los Angeles.

Grinewitschus, V., Lovrić, T., Rumler N., 2013. Influence of user behavior and home automation on energy consumption, Paper, 7th International Conference on Energy Efficiency in Domestic Appliances and Lighting (EEDAL'13), 11-13 September 2013, Coimbra, Portugal

Groß, M., Hoffmann-Riem, H., Krohn, W., 2005. Realexperimente: Ökologische Gestaltungsprozesse in der Wissensgesellschaft. Transcript, Bielefeld.

Hassenzahl, M., Laschke, M., 2013. Pleasurable Troublemakers, in: Walz, S., Deterding, S. (Eds.), The Gameful World. MIT Press, Boston (in press).

Hollstein, B., Straus, F. (Eds.), 2006. Qualitative Netzwerkanalyse. Konzepte, Methoden, Anwendungen. VS Verlag für Sozialwissenschaften, Wiesbaden.

Howaldt, J., Schwarz, M., 2010. Soziale Innovation im Fokus. Skizze eines gesellschaftstheoretisch inspirierten Forschungskonzepts, Transcript, Bielefeld.

Lamnek, S., 2010. Qualitative Sozialforschung Lehrbuch. Beltz, Weinheim/Basel.

Lang, D. J., Wiek, A., Bergmann, M., Stauffacher, M., Martens, P., Moll, P., Swilling, M., Thomas, C. J., 2012. Transdisciplinary research in sustainability science - practice, principles, and challenges. Sustainability Science 7 (Supplement 1), 25-43. 
Hassenzahl, M., Laschke, M., 2013. Pleasurable Troublemakers, in: Walz, S. \& Deterding, S. (Eds.), The Gameful World. MIT Press (in press).

Laschke, M., Hassenzahl, M., Diefenbach, S., 2011. Things with attitude: Transformational Products. Create1 1 Conference proceedings, 1-2

Leismann, K.; Schmitt, M., Rohn, H., Baedeker, C., 2013. Collaborative Consumption: Towards a Resource-Saving Consumption Culture. Resources 2(2013), 184-203.

Lettenmeier, M., Hirvilammi, T., Laasko, S., Lähteenoja. S., Aalto, K., 2012. Material Footprint of Low-Income Households in Finland-Consequences for the Sustainability Debate.

Sustainability 4(7), 1426-1447.

Lewin, K., 1951. Field theory in social science. Harper \& Row, New York.

Liedtke, C., Buhl, J., Ameli, N., 2013a. Microfoundations for Sustainable Growth with Eco-Intelligent Product Service-Arrangements. Sustainability 5(3), 1141-1160.

Liedtke, C., Hasselkuß, M., Welfens, M. J., Nordmann, J., Baedeker, C., 2013b. Transformation towards sustainable consumption: Changing consumption patterns through meaning in social practices, 4th International Conference on Sustainability Transitions, June 18-21, ETH Zurich, Switzerland. http://www.ist13.ch/submission/IST13_Full_Papers.pdf (Accessed 23 October 2013).

Liedtke, C., Welfens, M.J., Rohn, H., Nordmann, J. 2012a. Living Lab: User-Driven Innovation for Sustainability. International Journal of Sustainability in Higher Education. 13(2), 106-118.

Liedtke, C., Baedeker, C., von Geibler, J., Hasselkuß, M., 2012b. User-integrated Innovation: Sustainable LivingLabs, in: Fricke, V., Schrader, U., Thoresen, V.W. (Eds.), 2nd PERL International Conference "Beyond Consumption - Pathways to Responsible Living": Conference Proceedings, March 19th-20th 2012, Technical University Berlin, Germany, pp. 203-219.

http://www.aloenk.tuberlin.de/fileadmin/fg165/PERL_Conference_Proceedings_2012_14MB.pdf(Accessed 8 January 2013).

Loorbach, D., 2010. Transition Management for Sustainable Development: A Prescriptive, Complexity-Based Governance Framework. Governance: An International Journal of Policy, Administration and Institutions, 23(1,), 161-183.

Messerschmidt, J., 2012. Smart Submetering für die Wohnungswirtschaft: Niedrig-intensive Maßnahmen zur Energieverbruachssenkung bei Gebäuden. Energy 2.0 Kompendium 2012, 99. http://www.energy20.net/pi/index.php?StoryID=430\&issueID=205502 (Accessed 8January 2013).

Mont, O., 2004. Institutionalisation of sustainable consumption patterns based on shared use. Ecological Economics, 50(2004), 135-153.

Peters, A.; Sonnberger, M.; Dütschke, E.; Deuschle, J., 2012. Theoretical perspective on rebound effects from a social science point of view. Working Paper to prepare empirical psychological and sociological studies in the REBOUND project. Fraunhofer ISI.

Prell, C., 2012. Social network analysis : history, theory \& methodology. SAGE, Los Angeles/London.

Reckwitz, A., 2002. Toward a Theory of Social Practices. European Journal of Sociology, 5(2), 243263. 
Rockström, J. et al, 2009. A safe operating space for humanity. Nature 461, 461-472.

Rotmans, J., Loorbach, D., 2010. Towards a better understanding of transitions and their governance. A systemic and reflexive approach, in: Grin, J., Rotmans, J., Schot, J. (Eds.), Transitions to sustainable development - new directions in the study of long term transformation change. Routledge, New York, 105-220.

Røpke, I., 2009. Theories of practice: New inspiration for ecological economic studies on consumption. Ecological Economics 68(10), 2490-2497.

Sanders, E.B.N., Stappers, P.J., 2008. Co-creation and the new landscapes of design. Co-design 4(1), $5-18$.

Schelske, A., 2008. Transparente Märkte in interaktiven Wertschöpfungsprozessen. Synchrone Konsumforschung mit vernetzten Konsumenten, in: Schrage, D., Friederici, M.R. (Eds.), Zwischen Methodenpluralismus und Datenhandel. Zur Soziologie der kommerziellen Konsumforschung. VS Verlag, Wiesbaden, 167-191.

Schmidt-Bleek, F., 1994. Wieviel Umwelt braucht der Mensch? : MIPS - das Maß für ökologisches Wirtschaften, Birkhäuser, Berlin and others.

Schmidt-Bleek, F. et al., 1998. MAIA: Einführung in die Material-Intensitäts-Analyse nach dem MIPS-Konzept, Birkhäuser, Berlin and others.

Schneidewind, U., Scheck, H., 2013. Die Stadt als "Reallabor" für Systeminnovationen, in: RückertJohn, J. (Ed.), Soziale Innovation und Nachhaltigkeit. Perspektiven sozialen Wandels. Springer VS, Wiesbaden, pp. 229-248.

Schneidewind, U., 2010. Ein institutionelles Reformprogramm zur Förderung transdisziplinärer Nachhaltigkeitsforschung. GAIA 19(2), 122-128.

Scholz, R. W., Lang, D.J., Wiek, A., Walter, A.I., Stauffacher, M., 2006. Transdisciplinary case studies as a means of sustainability learning: Historical framework and theory. International Journal of Sustainability in Higher Education 7(3), 226 - 251.

Schuurman, D., Moor, K. D., Marez, L. D., \& Evens, T., 2011. A Living Lab research approach for mobile TV. Telematics and Informatics 28(4), 271-282.

Schweizer-Ries, P., 2013. Vom Wissen zum Handeln. Was führt zu umweltfreundlichem Verhalten?, in: Zschiesche, M. (Ed.), Klimaschutz im Kontext. Die Rolle von Bildung und Partizipation auf dem Weg in eine klimafreundliche Gesellschaft. oekom, München, pp. 27-40.

Sorrell, S., 2007. The Rebound effect : an assessment of the evidence for economy-wide energy savings from improved energy efficiency. UK Energy Research Centre, London.

Spaargaren, G., 2011. Theories of practice: Agency, technology, and culture. Exploring the relevance of practice theories for the governance of sustainable consumption practices in the new worldorder. Global Environmental Change 21, 813-822.

Spangenberg, H. J., 2002. Environmental space and the prism of sustainability: frameworks for indicators measuring sustainable development. Ecological Indicators, 295-309.

Sunikka-Blank, M., Galvin, R., 2012. Introducing the prebound effect: the gap between performance and actual energy consumption, Building Research \& Information 40:3, pp. 260-273.

Van den Bosch, S., 2010. Transition Experiments. Exploring societal changes towards sustainability, $\mathrm{PhD}$ thesis (Rotterdam: Erasmus Universiteit Rotterdam). 
Von Hippel, E., 1986. Lead Users: A Source of Novel Product Concepts. Management Science 32(7), 791-805.

Walther, G., 2010. Nachhaltige Wertschöpfungsnetzwerke. Überbetriebliche Planung und Steuerung von Stoffströmen entlang des Produktlebenszyklus. Gabler, Wiesbaden.

Warde, A., 2005. Consumption and Theories of Practice. Journal of Consumer Culture 5(2), 131-153.

Welfens, M.J. Liedtke, C. Rohn, H., Nordmann, J., 2010. Living Lab: Research and Development of Sustainable Products and Services Through User-Driven Innovation in Experimental-Oriented Environments. ERSCP-EMSU Conference "Knowledge Collaboration \& Learning for Sustainable Innovation", Delft.

Wood, G., Newborough, M., 2003. Dynamic energy-consumption indicators for domestic appliances: environment, behaviour and design, Energy and Buildings 35, pp. 821-841. 